\title{
Analisis Kebutuhan Telur Pada Penjual Jamu Di Kota Bengkulu
}

\author{
Analysis of Egg Needs in Herbal Medicine Sellers in Bengkulu City \\ Lola Fitaloka $^{1}$, Johan Setianto ${ }^{2}$, dan Hardi Prakoso ${ }^{3}$ \\ ${ }^{1}$ Program Studi Peternakan Fakultas Pertanian, Universitas Bengkulu \\ Jalan Raya W. R. Supratman, Kandang Limun, Bengkulu, 38371A \\ Corresponding e-mail: lolafitalokad4f@gmail.com
}

\begin{abstract}
This study aims to determine the need for eggs of herbal medicine sellers in Bengkulu City. This research was conducted in July 2018, the research method used is a survey method where data collection uses a questionnaire. The variables observed in this study include age, gender, formal education and length of business. Data were analyzed descriptively. The results showed that the overall respondents of herbal medicine sellers in Bengkulu City were male (100\%), respondents aged 24-34 were more dominant in selling jamu (40\%), had high school education (53.3\%), with a length of business of $1-14$ years (46.7\%). The eggs needed are 4,860 eggs / week, 19,320 eggs / month and 231,840 eggs / year.
\end{abstract}

Keywords: Needs, Eggs, Herbal Medicine

ABSTRAK

Penelitian ini bertujuan untuk mengetahui kebutuhan telur penjual jamu di Kota Bengkulu. Penelitian ini dilaksanakan pada bulan Juli 2018, Metode penelitian yang digunakan adalah metode survey dimana pengambilan data menggunakan kuisioner. Variabel yang diamati pada penelitian ini meliputi umur, jenis kelamin, pendidikan formal dan lama usaha. Data dianalisis secara deskiptif. Hasil penelitian menunjukkan bahwa responden penjual jamu di Kota Bengkulu keseluruhan berjenis kelamin laki-laki (100\%), responden dengan umur 24-34 lebih mendominasi dalam berjualan jamu (40\%), berpendidikan SMA (53,3\%), dengan lama usaha 1-14 tahun (46,7\%). Telur yang dibutuhkan sebanyak 4.860 butir telur/minggu, 19.320 butir telur/bulan dan 231.840 butir telur/tahun.

Kata Kunci: Kebutuhan, Telur, Jamu

\section{PENDAHULUAN}

Telur merupakan salah satu produk peternakan unggas yang memiliki kandungan gizi yang lengkap dan mudah dicerna. Telur adalah salah satu sumber protein hewani disamping daging, ikan, dan susu. Poerwosoedarmo dan Djaelani Sediaoetama (1997) juga mengemukakan bahwa telur merupakan bahan makanan yang bernilai gizi tinggi dan relatif murah dibandingkan sumber protein yang lain sehingga mudah dijangkau masyarakat.

Menurut Saliem et al. (2001), konsumsi telur lebih besar dari pada konsumsi hasil ternak lain, karena mudah diperoleh dan harganya relatif murah, sehingga terjangkau bagi anggota masyarakat yang mempunyai daya beli rendah. Di Indonesia telur ayam dibagi menjadi dua jenis, yaitu telur ayam Ras dan telur ayam Kampung. Telur ayam kampung memiliki ukuran lebih kecil, tetapi warna kuningnya lebih cerah. Telur ayam kampung asli mempunyai kelebihan dibanding telur ayam yang lain. Selain sumber kalori dan protein hewani yang cukup baik (mudah diserap usus dalam jumlah yang banyak) dapat dipakai sebagai racikan jamu yang diyakini dapat memberikan kesegaran pada tubuh, namun produksi telur ayam kampung masih 
terbatas. Ayam kampung hanya mampu memproduksi telur 39-130 butir per tahun (Binawati, 2008).

Kota Bengkulu sebagai pusat perekonomian, provinsi Bengkulu mengalami perkembangan yang cukup pesat. Hal ini tercermin dari jumlah penduduk dan pendapatan perkapita yang terus meningkat setiap tahunnya. Pada tahun 1996 penduduknya berjumlah 263.396 jiwa dengan tingkat pendapatan perkapita sebesar Rp 2.101.355 dan pada tahun 2012 penduduknya meningkat menjadi 319.100 jiwa dengan tingkat pendapatan perkapita Rp 15.950.642 (BPS kota Bengkulu, 2012). Peningkatan jumlah penduduk dan pendapatan perkapita berdampak pada peningkatan permintaan bahan makanan, salah satunya adalah telur.

Telur selain dikonsumsi oleh konsumen kseluarga, juga dikonsumsi oleh konsumen lembaga salah satunya adalah pedagang-pedagang obat tradisional yang memerlukan telur sebagai bahan baku utama. Hasil penelitian Sutriyani (1990) tentang analisis permintaan telur pada konsumen keluarga dan konsumen lembaga di Kecamatan Cempaka Putih DKI Jakarta. Adapun salah satu penjual obat tradisional yang memerlukan telur sebagai bahan baku utama adalah Jamu, belum terdapatnya catatan pasti mengenai permintaan telur oleh pedagang obat tradisional di Kota Bengkulu ini khususnya penjual Jamu menjadi latar belakang penelitian ini, sehingga diharapkan data yang diperoleh dari penelitian ini dapat dijadikan umber informasi mengenai jumlah permintaan telur oleh pedagang obat tradisional di Kota Bengkulu.

\section{METODOLOGI}

Penelitian ini dilaksanakan pada bulan Juli tahun 2018 di kota Bengkulu, jenis penelitian yang digunakan adalah penelitian kuantitatif (survey) yaitu digunakan untuk mendapatkan data dalam pengumpulan data dengan menggunakan daftar pertanyaan dan wawancara langsung yang digunakan pada penelitian ini yaitu metode survey, melakukan pendekatan langsung pada masyarakat penjual jamu di kota Bengkulu Lokasi penelitian dipilih secara purpositive sampling (disengaja), meliputi 15 responden penjual jamu di kota Bengkulu. Responden dipilih secara purpositive sampling (disengaja).

Data yang digunakan dalam penelitian ini yaitu data primer dan data sekunder. Pengambilan data primer diperoleh melalui pengamatan dan wawancara secara langsung. Wawancara dilakukan dengan menggunakan daftar pertanyaan atau kuisioner yang telah dipersiapkan. Sedangkan data sekunder yaitu data yang diperoleh dari study kepustakaan melalui literature dan instansi-instansi yang berhubungan dengan penelitian ini. Variabel Yang Diamati meliputi karakteristik responden (umur, pendidikan, lama usaha) dan Permintaan penjual jamu terhadap telur selanutnya data yang diperoleh disajikan dalam bentuk tabel dan akan dibahas secara deskriptif. 


\section{HASIL DAN PEMBAHASAN}

\section{Deskripsi lokasi penelitian}

Kota Bengkulu merupakan ibukota Propinsi Bengkulu yang terbentuk berdasarkan Undang-Undang Darurat Nomor 6 Tahun 1956 tentang Pembentukan Daerah Otonom Kabupaten-Kabupaten dalam Lingkungan Daerah Propinsi Sumatera Selatan. Sejak dikeluarkannya Undang-Undang Nomor 1 Tahun 1957, kota kecil Bengkulu diubah statusnya menjadi Kotapraja, meliputi 4 wilayah kedatukan yang membawahi 28 Kepangkuan. Berdasarkan Undang-Undang Nomor 9 Tahun 1967 Peraturan Pemerintah Nomor 20 Tahun 1968 Propinsi Bengkulu berdiri dan Kota Bengkulu dijadikan sebagai Ibukotanya. Berdasarkan Peraturan Pemerintah No.46 Tahun 1986 luas Kota Bengkulu adalah 144.52 Km2, sedangkan Berdasarkan hasil pengukuran tahun 2008 oleh Badan Koordinasi Survei dan Pemetaan Nasional (Bakosurtanal), Luas Kota Bengkulu adalah seluas $151.70 \mathrm{Km} 2$.

\section{Karakteristik responden}

Berdasarkan hasil penelitian karakteristik responden terdiri dari jenis kelamin, umur, pendidikan formal dan lama usaha yang dapat dilihat pada Tabel 1.

\section{Jenis Kelamin}

Berdasarkan hasil yang didapat karakteristik responden penjual jamu di Kota Bengkulu dapat dilihat pada Tabel 1, bahwa Keseluruhan responden (100\%) penjual jamu di kota Bengkulu berjenis kelamin laki-laki. Umumnya peran perempuan (istri maupun anggota keluarga yang lainnya) hanya membantu dalam menjalankan usaha penjualan jamu.

\section{Umur Responden}

Berdasarkan hasil yang didapat karakteristik responden penjual jamu di Kota Bengkulu dapat dilihat pada Tabel 1, Bahwa usia penjual jamu terbanyak adalah 24-34 tahun yang berjumlah sebanyak 6 orang (40\%), usia 35-45 tahun berjumlah sebanyak 3 orang (20\%), usia 46-56 tahun sebanyak 3 oang (20\%), serta usia 57-67 tahun ebanyak 3 orang (20\%). Kondisi ini menunjukkan bahwa rata-rata responden berada pada umur produktif yang memiliki kemampuan fisik yang mendukung dalam usaha penjualan jamu. Umur produktif merupakan tingkatan umur dimana seseorang mampu menghasilkan produk maupun jasa. Zainal et al., (2012) menyatakan bahwa umur antara 20-59 tahun merupakan umur yang produktif, sedangkan umur dibawah 20 tahun merupakan umur yang belum produktif dan dapat dikategorikan sebagai usia sekolah, sedangkan umur 59 titik produktivitasnya telah melewati titik normal dan akan menurun sejalan dengan berkurangnya umur.

\section{Pendidikan Formal}

Orang yang berpendidikan identik dengan orang yang berilmu pengetahuan, dan orang yang berilmu pengetahuan memiliki pola pikir dan wawasan yang tinggi dan luas. Pendidikan juga berperan penting dalam usaha peternakan karena merupakan modal dasar dalam 
meningkatkan kemampuan pola pikir penjual jamu dalam menerima berbagai informasi dan teknologi. Tingkat pendidikan penjual jamu di Kota Bengkulu SD sebanyak 3 orang (20\%), SMP sebanyak 2 orang (13,3\%), sebagian besar tamat SMA sebanyak 8 peternak dengan presentasi $(53,3 \%)$, strata 1 sebanyak 1 orang $(6,67 \%)$ dan strata 2 sebanyak 1 orang (6,67\%). Pendidikan seseorang penjual jamu merupakan salah satu faktor yang berpengaruh dalam usaha berjualan jamu, karena semakin tinggi tingkat pendidikan seseorang akan semakin mudah dalam menerima suatu teknologi yang dapat mendukung sehingga berpengaruh terhadap keberhasilan usahanya.

Pendidikan merupakan faktor penentu perbedaan pemikiran penjual jamu, dalam usaha berjualan jamu faktor pendidikan dapat membantu penjual untuk meningkatkan produksi dan produktifitas jamu yang dijual. Pendidikan sangatlah penting dan ini adalah salah satu faktor yang menjadi penunjang dalam menjalankan sebuah pekerjaan termassuk sebuah usaha. Hal ini dikatakan tingket pendidikan penting karena mempengaruhi para pelaku usaha dalam pedagang jamu dalam berfikir, bertindak dalam mengolah usahanya. Saediman (2012) mengungkapkan bahwa tingkat pendidikan tentunya akan berdampak pada kemampuan manajemen suatu usaha yang sedang dijalankan.

\section{Lama Usaha}

Pengalaman penjual jamu di Kota Bengkulu paling banyak pada rentang waktu 1-14 tahun yaitu sebanyak 7 responden atau 46,7\%, pada 15-25 yaitu 4 responden atau 26,7\% dan 2640 sebanyak 4 responden atau 26,7\%. Hastuti dan Supadi (2001), bahwa semakin lama usaha dapat menambah pengetahuan pengusaha yang banyak, sehingga keterampilan dalam menjalankan usaha penjualan jamu semakin meningkat.

Pengalaman usaha merupakan lama waktu yang telah dilalui penjual dalam menjalankan suatu bidang usahanya, semakin lama pengalaman yang dimiliki penjual jamu, maka dalam mengambil keputusan akan lebih bijak, pengalaman berjualan jamu diperoleh seseorang berdasarkan lama bergelut dalam usaha jamu yang dijalankan, pengalaman berjualan jamu merupakan faktor penting yang harus dimiliki penjual jamu untuk memutuskan segala kebijakan yang akan ditetapkan dalam usahanya.

Pengalaman dalam mengelola suatu usaha sangat berpengaruh terhadap prosess berjaannya usaha semakin banyak pengalaman maka semakin bermanfaat dalam pengambilan suatu keputusan demi kelancaran usaha tersebut, dalam dunia usaha lama usaha dapat dijadikan sebagai tolak ukur dalam memutuskan jual beli untuk masa yang akan datang, menurut Suherman (2003) bahwa pertambahan tingkat keterampilan diharapkan kepada para pedagang lebih dinamis, aktif dan terbuka dalam mengadopsi inovasi yang baru dan maju. 
Tabel 1. karakteristik responden penjual jamu di Kota Bengkulu.

\begin{tabular}{cccc}
\hline No & Keterangan & Jumlah Penjual Jamu (orang) & Persentasi (\%) \\
\hline 1 & Jenis Kelamin & & \\
& L & 15 & 100 \\
P & Jumlah & 15 & 0 \\
& Umur Responden (tahun) & Jumlah Penjual Jamu (orang) & Persentasi (\%) \\
\hline $24-34$ & 6 & 40 \\
$35-45$ & 3 & 20 \\
$46-56$ & 3 & 20 \\
& $57-67$ & 3 & 20 \\
& Jumlah & 15 & 100 \\
\hline 3 & Pendidikan Formal & Jumlah Penjual Jamu (orang) & Persentasi (\%) \\
SD & 3 & 20 \\
& SMP & 2 & 13,3 \\
SMA & 8 & 53,3 \\
S1 & 1 & 6,67 \\
S2 & 1 & 6,67 \\
& Jumlah & 15 & 100 \\
\hline 4 & Lama Usaha (tahun) & Jumlah Penjual Jamu (orang) & Persentasi (\%) \\
& 14 & 7 & 46,7 \\
& $15-25$ & 4 & 26,7 \\
& $26-40$ & 4 & 26,7 \\
& Jumlah & 15 & 100 \\
\hline
\end{tabular}

Sumber : Data primer telah diolah, 2018

\section{Kebutuhan Telur}

Berdasarkan hasil yang didapat kebutuhan telur seluruh penjual jamu di Kota Bengkulu dapat dilihat pada Tabel 2.

Tabel 2. Jumlah kebutuhan telur penjual jamu

\begin{tabular}{ccc}
\hline No & Keterangan & jumlah kebutuhan telur/minggu (butir) \\
\hline 1 & responden 1 & 210 \\
2 & responden 2 & 210 \\
3 & responden 3 & 210 \\
4 & responden 4 & 450 \\
5 & responden 5 & 210 \\
6 & responden 6 & 210 \\
7 & responden 7 & 90 \\
8 & responden 8 & 150 \\
9 & responden 9 & 330 \\
10 & responden 10 & 1470 \\
11 & responden 11 & 420 \\
12 & responden 12 & 120 \\
13 & responden 13 & 210 \\
14 & responden 14 & 300 \\
15 & responden 15 & 270 \\
\hline
\end{tabular}

Sumber : Data primer telah diolah, 2018 


\begin{tabular}{ccc}
\hline No & Keterangan & jumlah kebutuhan telur/bulan (butir) \\
\hline 1 & responden 1 & 840 \\
2 & responden 2 & 840 \\
3 & responden 3 & 840 \\
4 & responden 4 & 1800 \\
5 & responden 5 & 840 \\
6 & responden 6 & 840 \\
7 & responden 7 & 360 \\
8 & responden 8 & 600 \\
9 & responden 9 & 1320 \\
10 & responden 10 & 5880 \\
11 & responden 11 & 1680 \\
12 & responden 12 & 480 \\
13 & responden 13 & 840 \\
14 & responden 14 & 1200 \\
15 & responden 15 & 960 \\
\hline
\end{tabular}

Sumber : Data primer telah diolah, 2018

\begin{tabular}{ccc}
\hline No & Keterangan & jumlah kebutuhan telur/tahun (karpet) \\
\hline 1 & responden 1 & 10080 \\
2 & responden 2 & 10080 \\
3 & responden 3 & 10080 \\
4 & responden 4 & 21600 \\
5 & responden 5 & 10080 \\
6 & responden 6 & 10080 \\
7 & responden 7 & 4320 \\
8 & responden 8 & 7200 \\
9 & responden 9 & 15840 \\
10 & responden 10 & 70560 \\
11 & responden 11 & 20160 \\
12 & responden 12 & 5760 \\
13 & responden 13 & 10080 \\
14 & responden 14 & 14400 \\
15 & responden 15 & 11520 \\
\hline & Jumlah & 231.840 \\
\hline
\end{tabular}

Sumber : Data primer telah diolah, 2018

Berdasarkan hasil yang didapat kebutuhan telur seluruh penjual jamu di Kota Bengkulu dapat dilihat pada Tabel 2, bahwa 15 responden penjual jamu di Kota Bengkulu membutuhkan telur sebanyak 4860 butir telur dalam 1 minggu, 19320 butir telur dalam 1 bulan dan 231840 butir telur dalam 1 tahun.

Telur yang digunakan oleh penjual jamu sebagai bahan racikan jamu rata-rata didapatkan dengan cara berlangganan baik dengan perusahaan ayam petelur secara langsung maupun pasar . Dengan harga Rp. 40.000-55.000/karpet telur ayam kampung dan Rp. 70.000-80.000/karpet telur bebek, jamu yang umumnya dijual oleh penjual jamu di Kota Bengkulu adalah jamu untuk stamina dengan harga Rp. 20.000-25.000/gelas. 


\section{KESIMPULAN}

Berdasarkan hasil penelitian mengenai kebutuhan telur oleh penjual jamu di Kota Bengkulu dapat disimpulkan bahwa, telur yang dibutuhkan oleh 15 responden penjual jamu tersebut adalah sebanyak 4860 butir telur dalam 1 minggu, 19320 butir telur dalam 1 bulan dan 231840 butir telur dalam 1 tahun.

\section{DAFTAR PUSTAKA}

Badan Pusat Statistik Provinsi Bengkulu (2012). Provinsi Bengkulu Dalam Angka. Badan Pusat Statistik Provinsi Bengkulu.

Binawati, D. K. 2008. Pengaruh laserpunktur terhadap kualitas telur ayam arab. Journal of Science 02 (01): 28-34.

Poerwosoedarmo dan Djaelani Sediaoetama (1997). Dasar-dassar Ilmu Telur. Fakultas Peternakan universitas Diponegoro, Semarang.

Saediman, 2012. Pengaruh skalah usaha terhadap pendapatan peternak ayam buras petelur di kecamatan maritengngae kabupaten sidrap. Skripsi. Universitas Hasanuddin. Makasar Sugeng, Y.B. 2000. Sapi potong. PT. Penebar Swadaya. Jakarta.

Saliem, H. P., E. M. Lakolo, T. B. Purwantini, M. Ariani dan Y. Marisa. 2001. Analisis ketahanan pangan tingkat rumah tangga dan regional. laporan hasil pelitian. Pusat Penelitian dan Pengembangan Sosial Ekonomi Pertanian.Bogor.

Suherman, 2003. Strategi pembelajaran Matematika Kontemporer. Bandung: PT Remaja Rosdakarya.s

Sutriyani, Y. 1990. Analisis permintaan telur ayam ras pada konsumen keluarga dan konsumen lembaga di Kecamatan Cempaka Putih DKI Jakarta. Skripsi. Fakultas Peternakan, Institut Pertanian Bogor.

Zainal. H, Sartika. T, Zainudin. D, Komarudin. 2012. Local chiken crossed of kub, sentuland goak to increase national poultry meat production. Workshop Nasional Unggas Lokal. Balai Penelitian Ternak Bogor. 